\title{
A Review on the Critical Factors Causing Delay of Delivery Time in Construction Projects
}

\author{
Shitaw Tafesse* \\ *Dilla University, College of Engineering and Technology, Department of Construction Technology and Management, \\ Dilla, Ethiopia
}

Tel: +251922311029 (shitu.taf@gmail.com)

Received: 22.10.2020 Accepted: 28.02.2021

\begin{abstract}
Completing the construction projects as per the scheduled time is an underlined issue for the success of the projects. However, several construction projects are confronted in completing within the agreed contractual project duration. In addressing influential factors contributing to delay of delivery time in construction projects, a remarkable number of studies have been conducted and published over the past decades. However, it seems that a summary and organizing of the research development in this discipline is not popularized. Therefore, this paper aims to review the existing research trend on the factors causing delays in construction projects. The review is very useful for industry practitioners and scholars to provide comprehensive and precious sources. Also, it provides a discussion, conclusion, and future research directions.
\end{abstract}

Keywords: Causes of delay, Construction projects, Delay of delivery time, Research review

\section{Introduction}

The completion of construction projects within the estimated or agreed project duration is one of the most important aspects of the project's success, where, time, cost, quality, and safety are the key objectives of construction projects [1]. In another word, the success of a construction project is measured using key parameters such as completion within schedule and allocated budget, whether the project was completed according to specification, whether the project meets the expectations of the client, and the extent of variations [2]. Projects or construction works that are not delivered on time to the client are referred to as delayed projects [3], almost all projects around the world suffer from delays [4]. The main part of the countries' capital is allocated for construction projects, most of which are completed with delay [5].

Time overrun in the construction industry becomes a common problem and it is a project slipping over its planned schedule. It is believed that delay is one of the top problems in the construction industry [7], many projects experience extensive delays and thereby exceed initial time and cost estimates [8], especially the mega or complex projects of today, with many interfaces [6]. Time is the crucial element in any construction projects, along with cost and quality [9], time overrun has become a global challenge in the construction industry [9]. Assaf \& Al-Hejji, [10], further illustrates that to the owner, the delay means loss of revenue through lack of production facilities and rentable space or dependence on present facilities. It reported as one of the most common problems causing negative effects on the construction projects, participating parties and is often responsible for turning profitable projects into failed ventures [5]. If the delay has occurred in construction projects, it hurts project success in terms of time, cost, quality, and safety, which are a major source of claims and disputes $[1,11]$.

Arshi \& Sameh, [1], describe that the effects of construction delays are not only to the construction industry, but to influence the overall economy of a country, as construction plays a major role to development and contributes to the GDP. A research result indicates that; time overrun cost overrun, low 
productivity, acceleration losses, contract termination, poor quality, and disputes among construction stakeholders are some of the effects of delay on construction projects [12, 13], which have an extremely negative effect on construction projects [14].

The success of construction companies in terms of time should be given special attention to improve the progress of construction and development of countries [15]. Delays can be prevented or reduced if it source or major delay factors are identified and handled on time [16]. To identify the source of delay, several researches have been widely conducted; however, this discipline lacks summarized and well-organized sources. To this end, this research aims to review the existing research trend focused on delay cause of delivery time in construction projects. As a result, it provides comprehensive factors of delay to the construction stakeholders, researchers, institutions, policymakers, and others. Consequently, it will play a vital role in gaining in-depth insights on the advancement of this research field, preventing the duplication of research efforts, and help to explore new and valuable research ideas.

\subsection{Nature of Construction Delays}

According to the Oxford Dictionary, delay is defined as lateness or slowness, postponement of projects. It is also described in the previous research using different terminologies, the same idea or meaning is intended. This is mainly due to the term's global use and its effects not only on the construction industry but also on the overall economy as well. Delay is simply defined as 'the inability to meet the scheduled time [14], or it described as the extension of time to complete the construction project [18], and "it is the difference between a project's original contract period at the time of bidding and its overall final contract period at the end of the construction project" [19]. At the same time, schedule delay refers to a situation where a construction project does not come to completion within the planned period [20]. It is also described as the time overrun either beyond a completion date specified in a contract or beyond the date that the parties agreed upon for project delivery [10], which is considered one of the most recurring problems in the construction industry [1].

In terms of the construction contract, it has no precise meaning but characterizes the condition of the project execution [17]. Thus, the term is widely used to describe the postponement or extension of time for any activities in a project [21]. Previous studies defined delay as time overruns that go beyond the completion date as specified in the contract document or beyond an extension of time granted [17]. In general, construction delay is defined as follows [22];

1. Delay causing the suspension of one or more completion dates of the construction project,

2. Prolongation of the contractor's and/or subcontractors time-related costs,

3. Delay to progress causing loss and/or expense to be suffered by contractors/subcontractors,

4. Reduction in productivity (or disruption) causing loss and/or expense to be suffered by contractors or subcontractors.

\subsection{Types of Delays}

Various research was reviewed to understand the nature and the types of delays of delivery time in the construction industry. Trauner, [23], described four different types of delays, namely critical or non-critical, excusable or non-excusable, compensable or non-compensable, and concurrent or nonconcurrent.

Critical delays are the delays that affect the progress of a project and modify the completion dates [9]. On the other hand, delays that occur in construction projects without affecting project completion or milestone dates are non-critical delays [23]. Whereas, non-excusable delays result from the action or inaction of the contractors [24], which caused solely by the contractor or its suppliers [25]. An example of a non-excusable delay would be when a contractor fails to provide sufficient man-power to complete the job on time [26].

Excusable delays are further classified into two types, noncompensable or compensable excusable delays. Noncompensable delays are caused by third parties or incidents beyond the control of either the owner or the contractor and are not attributable to any of the parties [25]. Examples typically include acts of God, unusual weather, strikes, fires, acts of government in its sovereign capacity, etc. In this case, the contractor is normally entitled to a time extension but no compensation for delayed damages [27]. Compensable delays are caused by the owner or the owner's agents [28]. It occurs when the owner or the consultant has delayed the contractor in the completion of the work [29]. Compensable delay usually leads to a schedule extension and exposes the owner to financial damages claimed by the contractor [27]. 
INTERNATIONAL JOURNAL Of ENGINEERING TECHNOLOGIES-IJET

Tafesse, Vol.6, No.4, 2020

\subsection{Causes of Delay}

The major source of construction delay has been divided or classified in different ways according to context of different research results. For instance, the major groups or category factor that causes a delay in construction projects are contractors, consultant, owner, material, equipment, and labor [3]. Delays cause for building construction projects of Ghana explored by Frank \& Adwoa, [28]. Based on the findings, material, man-power, equipment, financing, environmental, changes/variation, government action, contractual relation, and scheduling and controlling techniques are the main crucial factors causing delays. Hamed, et al., [30], assessed the main causes of construction delay in Iran. The result from this study revealed that; owner, contractor, consultant, and law regulations are factors that have an impact on scheduled project time.

Many studies have been carried out to explore the causes of delay in construction projects. Wa'el, et al., [31], studied the causes of delay in construction projects in Malaysia. The results showed that the main contributor to time overrun is contractor's factors, owner's factors, consultant's factors, and external factors. While other researchers explore the sources of delay into factors during tendering, general factors, factors after tendering, and factors before tendering [32]. According to Jeffrey, et al., [33], client, contractor, consultant, labor and equipment, material, and others are the critical delay factors for construction projects in Malaysia. It is also reported that; owner, consultant, contractor, material, labor, equipment, project, and external [34]. Construction delay cause factors explored and classified into eight classes which were; project, client, design, contractor, material, labor, plant/equipment, and external factors [35].

Causes of schedule delays in building construction projects in Vanuatu have been studied by [36]. The finding of this research indicates that eight types of the main categories delay causes in building construction projects which are; site characteristics, equipment, labor, material, managerial, information, financial, and other issues are the significant factors. A substantial amount of studies have been found in this discipline and were explored different categories of main delay factors. For example, the factors that caused the delay in construction projects are categorized as the owner, contractor, consultant, material, equipment, labor, and external related factors [3]. Arshi \& Sameh , [1], outlined significant factors causing a delay in the UAE construction industry. The study shortlisted seven categories of delay which are; owner, financial, planning and scheduling, contractual relationship, government regulation, and unforeseen condition. Owner, contractor, consultant, law regulation, and others are the main categories of delay in the case of Iran construction projects [30].

An empirical study in the Ethiopian construction sector by Tsegay \& Hanbin, [37], argue that client, contractor, consultant, designer, resource (material, finance, equipment, and labor), contract condition, and external related causes are the main category of delays. The study focused on analyzing delay causes and effects in Ghanaian state housing construction projects by Charles, et al., [38], listed 37 causes of delay grouped under ten categories. Financial, resource, technical, economic, environmental, operational, government and political, relationship, and safety or security are the major categories contributing to delay as obtained from the study. Aliyeh, et al., [5], researched to identify and prioritize delay factors in Iran's oil construction projects. The study shows the causes of delay in construction projects classified under ten categories namely, owner, contractor, consultant, equipment, labor, materials, design, contract, and contractual relations, laws and regulations, and environmental factors.

Australian construction delay risks were studied by Hossein, et al., [39]. The results from the study reported that stakeholders, resources, and processes were the critical factors of time overrun. Charles, et al., [40], exploring critical road project delay factors in Ghana and grouped them into four main classes which are; client, consultant, contractor, and supplier related causes. A study aims to analyze the causes of construction delays in Egyptian residential projects by Tarek \& Mohamed, [41], explored and classified the important factors leading to delay in delivery time into eight groups. The main classification of the major causes of delay in Egyptian residential projects are; owner, consultant, contractor, material, labor, equipment, project, and external related factors.

For this study, 78 critical factors causing construction delays were collected. To extract factors that cause delay, [42, $43,29,44,45,28,46,47,48,49]$, have been used for this purpose. Also, the studies in which the factors causing delay in construction were collected and identified from [35, 50, 3, 34, 36, 51, 37, 52, 32, 53]. Furthermore, [5, 33, 14, 38, 39, 54, 38, $40,41]$, were reviewed to collect the main and sub-factors of causing time overrun in construction projects. In general, in this review, an inclusive category on the causes of construction delay was identified after the detailed review of the published articles. Based on the summary, the following are eight major categories of delays in construction projects mainly, (1), contractors related causes, (2), client-related causes, (3), consultant related causes, (4), material related causes, (5), equipment related causes, (6), 
labor-related causes, (7), finance-related causes, and (8) external causes. The summarized categories and the respective sub- factors contributing to causes delay in construction projects are presented in Table 1.

Table 1: The major category and factors causing delays

\begin{tabular}{|c|c|c|}
\hline No & Factors causing delay & Category \\
\hline 1 & Planning and scheduling problems & Contractor \\
\hline 2 & Poor qualification of the contractor's technical staff & \\
\hline 3 & Poor communication and coordination with other parties & \\
\hline 4 & Improper pricing by contractors to win the bid & \\
\hline 5 & Poor site management and supervision & \\
\hline 6 & Delays in site mobilization & \\
\hline 7 & Rework due to construction defects and errors & \\
\hline 8 & Improper construction methods & \\
\hline 9 & Subcontractors related problems & \\
\hline 10 & Inadequate contractor experience & \\
\hline 11 & Inaccurate cost estimates & Client \\
\hline 12 & Improper selection of subsequent consultants & \\
\hline 13 & Late decision-making process & \\
\hline 14 & Change order by the owner during construction & \\
\hline 15 & Lack of client experience in construction & \\
\hline 16 & Late revising and approving design documents & \\
\hline 17 & Suspension of work by the owner & \\
\hline 18 & Interference on the execution of work & \\
\hline 19 & Late in site delivery for construction work and design & Consultant \\
\hline 20 & Improper project feasibility study & \\
\hline 21 & Ineffective delay penalties & \\
\hline 22 & Delay in approving major changes of the work & \\
\hline 23 & Insufficient data collection and survey before the design & \\
\hline 24 & Poor supervision and management & \\
\hline 25 & Delays in producing design documents & \\
\hline 26 & Poor communication and coordination & \\
\hline 27 & Unclear and inadequate details in drawings & \\
\hline 28 & Lack of advanced engineering design software & \\
\hline 29 & Inadequate experience of a consultant & \\
\hline 30 & Late in approving and receiving of complete work & \\
\hline 31 & Waiting time for approval of tests and inspection & \\
\hline 32 & Late in the ordering of materials & Material \\
\hline 33 & Poor quality of materials & \\
\hline 34 & Unavailability of specified materials in the market & \\
\hline 35 & Damage of sorted material while they are needed urgently & \\
\hline 36 & Poor procurement of construction materials & \\
\hline 37 & Delivery of wrong materials & \\
\hline 38 & Changes in material types and specification & \\
\hline 39 & Shortage of materials & \\
\hline 40 & Unreliable suppliers & \\
\hline 41 & Inappropriate storage of materials leading to damages & \\
\hline
\end{tabular}


INTERNATIONAL JOURNAL Of ENGINEERING TECHNOLOGIES-IJET

Tafesse, Vol.6, No.4, 2020

\begin{tabular}{|l|l|l|}
\hline 42 & Use of outdated equipment & \\
\hline 43 & A frequent damage of construction plant and equipment & Equipment \\
\hline 44 & Insufficient or shortage of equipment & \\
\hline 45 & Lack of high-technology mechanical equipment & \\
\hline 46 & Low productivity and efficiency of the equipment & \\
\hline 47 & Shortages of skilled operators & \\
\hline 48 & Shortage of equipment parts & \\
\hline 49 & Equipment allocation problems & Labour \\
\hline 50 & The low productivity level of workers & \\
\hline 51 & Shortage of labor & \\
\hline 52 & Conflicts among workers and discipline problem & \\
\hline 53 & Labor absenteeism & \\
\hline 54 & Work permits of workers & \\
\hline 55 & Less motivation and morale & \\
\hline 56 & Unqualified/inexperienced workers & \\
\hline 57 & Labor accidents and injuries & \\
\hline 58 & Shortages of technical personnel & \\
\hline 59 & The problem of the process of financial claims & \\
\hline 60 & Government funding processes & \\
\hline 61 & Financial difficulties and economic problems of stakeholders \\
\hline 62 & Late release budget/ funds & \\
\hline 63 & Global financial crisis & \\
\hline 64 & Change in economic factors & \\
\hline 65 & Inadequate fund allocation & \\
\hline 66 & Inflation of the local currency & \\
\hline 67 & Weather effect & \\
\hline 68 & Political interference & \\
\hline 69 & Delay in obtaining permits from the municipality & \\
\hline 70 & Traffic control and restriction at the job site & \\
\hline 71 & Force majeure & \\
\hline 72 & Accident during construction & \\
\hline 73 & Changes in government regulations and laws & \\
\hline 74 & Corruption & \\
\hline 75 & Effect of social and cultural factors & \\
\hline 76 & Policy and commitment of the government & \\
\hline 77 & Unavailability and delay in providing utilities & \\
\hline 78 & Unexpected geological and site conditions & \\
\hline
\end{tabular}

\section{Methodology}

The review methods from previous research [55, 56], were used to offer valuable guidance in writing and selecting target academic journals. Ke, et al., [57], stated that a research team might contribute their research achievements to a renowned journal from their specific field or that which has a similar research topic. Identifying the research question, identifying relevant studies, study selection; organizing the data; and ordering, summarizing, and reporting the results were the procedure followed for the study, the same methods were adopted by [54]. Accordingly, in this review Scopus, Science direct, cross-reference, Google Scholar, Semantic Scholar, and direct google search engine were used to identify the journals that have published the most research on delay of delivery time in construction projects between the periods 2002 to 2020 . The 
literature selection was based on keywords that were construction delay, construction project time, success in construction, causes of delay, delivery time, and time extension. Articles containing these terms in the title, abstract, and keywords were considered for this research. A total of 60 research in all were consulted and relevant data for the review and discussion purpose were found in forty (40) researches.
Then important information was picked from the selected articles for content analysis and discussion purposes. The reviewed papers have used different types of research methodology. The data collection procedure and source of data, research participant, study area, data processing method, and sector in which the studies conducted have been identified for some of the reviewed papers and outlined in Table 2

Table 2: Brief information of the review papers methodology

\begin{tabular}{|l|l|}
\hline Source of data & Previous research \\
\hline Literature & {$[29,28,17,3,1,30,32,36,58,34]$} \\
\hline Questionnaire & {$[29,28,17,3,1,30,32,36,58,34]$} \\
\hline Interview & {$[29,36,34]$} \\
\hline Case study & {$[32,34]$} \\
\hline Document review & {$[44,48]$} \\
\hline Data analysis method & \\
\hline Simple percentage & {$[29,28,36]$} \\
\hline Relative importance index & {$[28,1,30,32,36]$} \\
\hline Principal component analysis & {$[17]$} \\
\hline Descriptive statistics & {$[3,47]$} \\
\hline Mean score, standard deviation & {$[58,35,16,45]$} \\
\hline Frequency, severity and importance index & {$[34,33]$} \\
\hline Scope of study & \\
\hline Construction & {$[29,3,1,30,32,34,35]$} \\
\hline Building/housing/private housing projects & {$[28,17,36,58]$} \\
\hline Road/highway projects & {$[50,53]$} \\
\hline Ground water/sewer project & {$[42,43]$} \\
\hline Gas pipeline/oil construction project & {$[48,5]$} \\
\hline Participant of the study & \\
\hline Contractors & {$[29,28,17,1,30,32,36,34]$} \\
\hline Consultants & {$[29,28,17,1,30,32,36,34]$} \\
\hline Clients & {$[29,28,17,1,30,32,36,34]$} \\
\hline Construction professionals & {$[3,35]$} \\
\hline Private housing developer & {$[58]$} \\
\hline Government employees & {$[46]$} \\
\hline &
\end{tabular}

As it is depicted in Table 2, the major source of data was a literature review, interview, questionnaire, document review, and case study for the reviewed papers. The study sector of the research is also construction sectors in general, building and housing projects, gas pipeline project water, and sewer projects. The most widely used analysis method used in the research is the relative importance index, simple percentage, average score, and descriptive analysis method like mean score and standard deviation. The data for the reviewed papers are collected from contractors, consultants, clients, government bodies, and other professionals in the construction sectors. 


\section{Results and Discussion}

The reviewed papers are classified according to their year's year of publication. Concerning the year of the publication, it is widely cover from the year 2002 to 2020 . A total of 40 papers appearing from 2002 to 2020 are included for this purpose. Based on the analysis result of this review a maximum of $10 \%$ (4 papers) is published in each of 2013, 2015, 2016, 2017, and 2020. At the same time, the second-highest ranked $7.5 \%$ (3 papers) appeared per the years $2006,2007,2014$, and 2019. It is followed by $5 \%$ ( 2 papers) in the year 2008. The minimum number of research articles $2.5 \%$ (1 paper) released in 2002, 2003, 2009, 2010, 2011, and 2012. No papers have been found in the years 2004, 2005, and 2018 for this case. Figure 1 below outlines the reviewed papers distribution based on the year of publication.

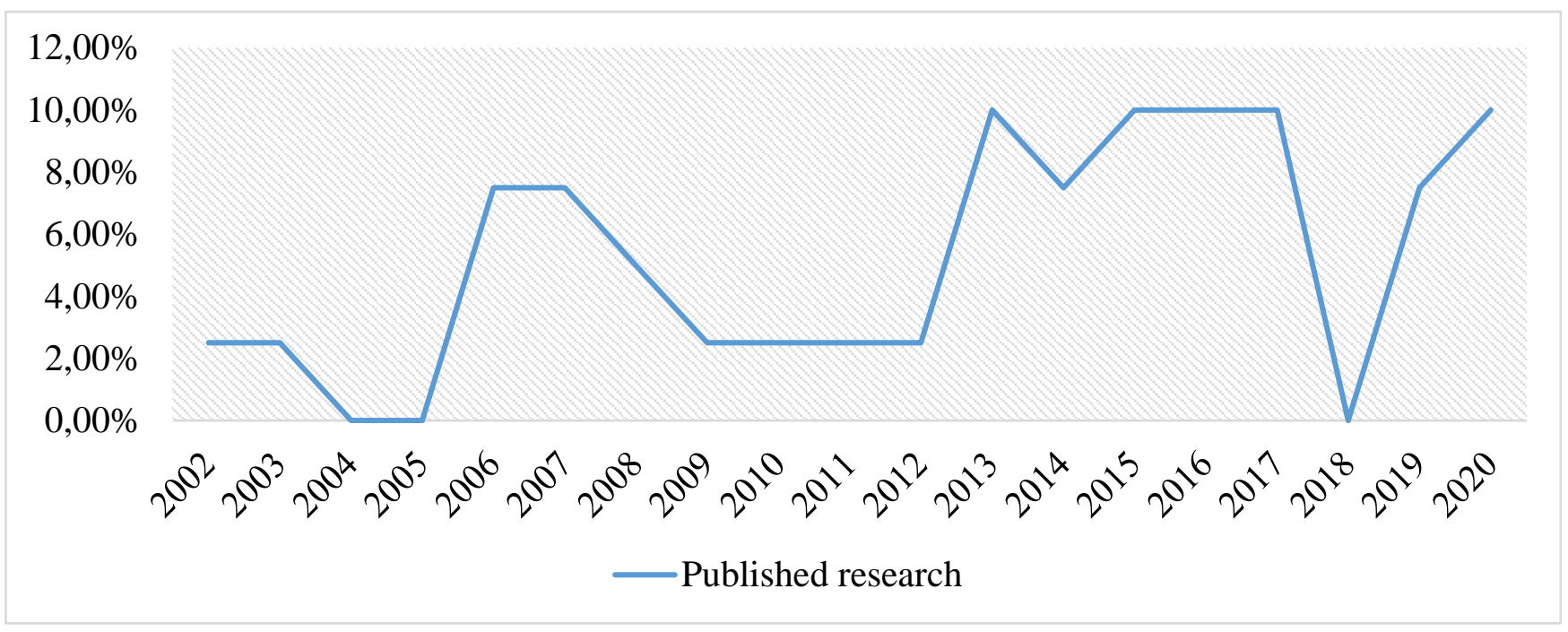

Figure 1: The reviewed papers distribution based on year of publication

In this review, the published papers were also identified based on the country distribution in which the study is specifically conducted. Based on the information investigated out of 40 papers, the maximum papers are found from Malaysia which is $9(22.50 \%)$ papers in numbers followed by Ghana has $6(15 \%)$ papers based on country-wise distribution. The third rank country based on the number of published papers related to construction delay is Egypt which accounts for $12.50 \%$ (5 papers) over the other reviewed papers. Whereas Iran, Pakistan, Ethiopia, Nigeria, and Jourdan have accounts for $6.67 \%$ (2 papers each). The remaining papers are found from Zambia, UAE, Saudi Arabia, Vanuatu, India, Turkey, Australia, Kuwait, Gaza Strip North Ireland, and Oman in which 1 research paper $(2.5 \%)$ was found from each country out of the remaining papers. 


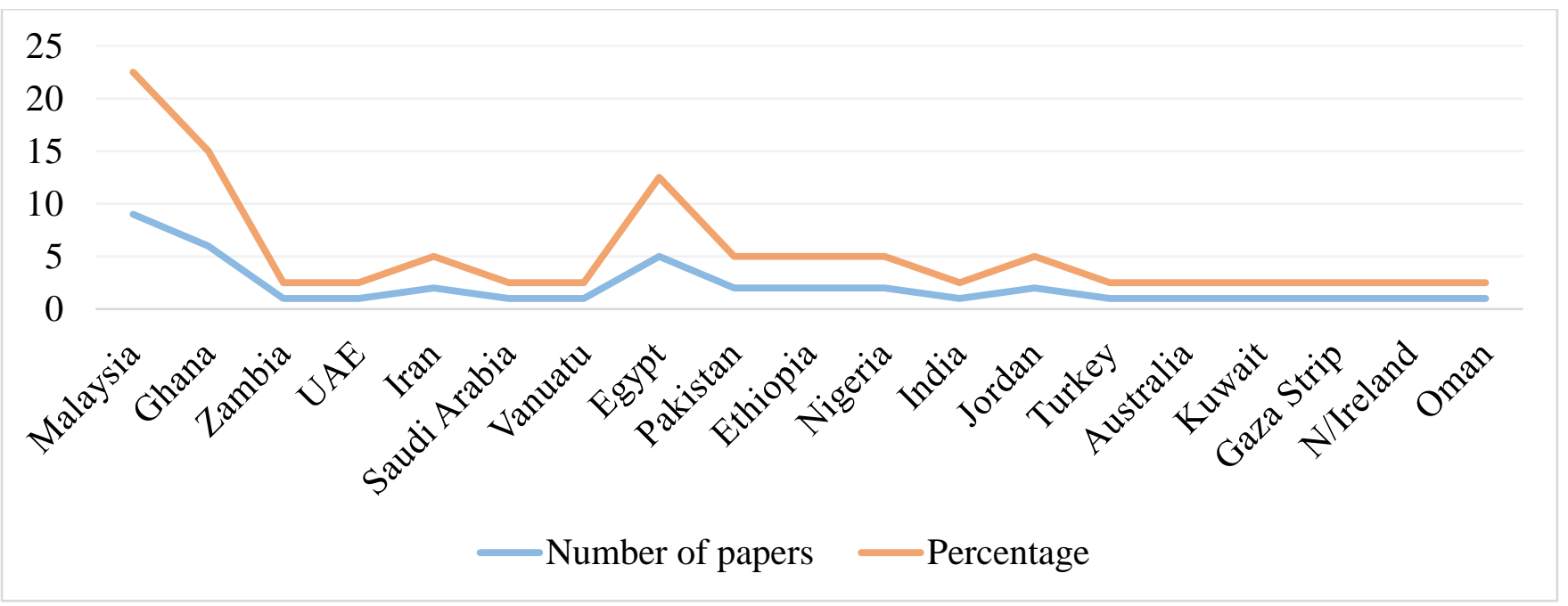

Figure 2: The reviewed papers based on the country distribution

Some of the research papers have been presented according to the respective journal that the papers appear and the publisher.
Table 3 presented the journal of the papers, the publisher, and the number of articles per each of the reviewed articles.

Table 3: Journal, publisher, and number of papers per Journal

\begin{tabular}{|c|c|c|c|}
\hline No & Journal & Publisher & $\begin{array}{l}\text { No. of } \\
\text { publication }\end{array}$ \\
\hline 1 & Engineering, Construction and Architectural Management & Emerald Publishing Limited & 3 \\
\hline 2 & $\begin{array}{l}\text { International Journal of Energy } \\
\text { Sector Management }\end{array}$ & Emerald Publishing Limited & 1 \\
\hline 3 & Journal of Economic and Administrative Sciences & Emerald Publishing Limited & 1 \\
\hline 4 & Journal of Facilities Management. & Emerald Publishing Limited & 1 \\
\hline 4 & International Journal of Managing Projects in Business & Emerald Publishing Limited & 2 \\
\hline 5 & Journal of Engineering, Design, and Technology & Emerald Publishing Limited & 1 \\
\hline 6 & Journal of Financial Management of Property and Construction & Emerald Publishing Limited & 2 \\
\hline 7 & Alexandria Engineering Journal & Elsevier BV & 3 \\
\hline 8 & Journal of Construction Engineering And Management & ASCE & 2 \\
\hline 9 & Construction Management and Economics & Routledge & 2 \\
\hline 10 & Australasian Journal of Construction Economics and Building & UTS ePREESS & 1 \\
\hline 11 & Journal of Construction in Developing Countries & Universiti Sains Malaysia & 5 \\
\hline 12 & HBRC Journal & Elsevier BV & 1 \\
\hline 13 & J. Korea Inst. Build. Const & $\begin{array}{l}\text { Korea Institute of Building } \\
\text { Construction }\end{array}$ & 1 \\
\hline 14 & Journal of Advanced Research & Elsevier BV & 1 \\
\hline 15 & Procedia - Social and Behavioral Sciences & Elsevier Ltd & 1 \\
\hline 16 & International Journal of Project Management & Elsevier Ltd and IPMA & 1 \\
\hline 17 & Procedia Engineering & Elsevier Ltd & 1 \\
\hline 18 & International Journal of Project Management & Elsevier Science Ltd and IPMA & 1 \\
\hline
\end{tabular}


INTERNATIONAL JOURNAL Of ENGINEERING TECHNOLOGIES-IJET

Tafesse, Vol.6, No.4, 2020

\subsection{Top Ranked Causes of Delays}

It is evident that the significant factors causing a delay in the UAE construction industry are preparation and approval of drawings [1], delays in building construction projects in Ghana occurred due to the delay of the owner to honoring payment certificates for the contractor [28]. Based on the Saudi public construction projects, focus on financial analysis and awarding the lowest bidder were the highest-ranked causes of delay [32], while, common ownership is the main source of schedule delays in building construction projects in Vanuatu [36]. A study on imperative causes of delays in construction projects indicates that weather conditions are the first ranked cause of delay [58], a report in Lagos State, Nigeria shows that an insufficient amount of equipment is a factor influencing contractors' performance and causes delay [35]. Improper planning, site management, inadequate contractor experience, finance, and payments of completed work were the highest-ranked causes of delay in the Malaysian construction industry [59].

An empirical study on the analysis of delay impact on construction projects in Ethiopia reported that corruption, unavailability of utilities at site, inflation or price increases in materials, lack of quality materials, late design, and design documents were the major causes of delay based on the RII analysis results [37]. Samiullah, et al., [53], investigated the identification of causes and minimization of delays in Pakistan highway projects. Poor site management, inadequate contractor experience, and poor communication among construction parties were the top three ranking factors based on the mean score from the questionnaire survey [53]. Survey results and analysis on the causes of delay in construction of groundwater projects in developing country in the case of Ghana is evident that monthly payment difficulties, poor contract management, material procurement inflation, and contractor's financial difficulties found to be the most causative factor [43].

In public building construction projects in the case of Addis Ababa administration, Ethiopia, the significant factors contributing to delays are difficulty in project financing (poor financial system), poor project management system, delay in the issuance of design and drawing, shortage of availability of imported materials and goods on the market, error, and complexity of the design [52]. Contractors' financial difficulties, clients' cash flow problems, architects' incomplete drawings, slow mobilization, equipment breakdown, and maintenance problems were recommended as the highest causative factors in Nigeria construction [44]. Depending on the analysis results on the factors affecting delays in construction projects in India, delay in material delivery by vendors, non-availability of drawing/design on time, financial constraints of the contractor, increase in the scope of work, and obtaining permissions from local authorities were a critical source of time overrun [47].

According to Murat, et al., [49], inadequate contractor experience, poor site management and supervision, ineffective project planning and scheduling, design changes by the owner or his agent during construction, late delivery of materials, unreliable subcontractors are influential factors causing delay based on the RII analysis results in Turkey construction projects. Following the results of the study in Iran gas pipeline projects, low ability of the contractor to provide imported material, unrealistic contract durations imposed by the client, slow delivery of material by the client, slow land expropriation due to resistance from occupants, and clients' change orders or large quantities of extra work are the critical factors for delay causes [48]. Abdalla \& Hussien, [42], investigated the causes of construction delays. Inadequate contractor experience, finance and payment of completed works, subcontractors, owner interference, and slow decision making by the contractor were determined as the most prioritized factors. An analysis on the exploration of causes for delay in construction projects by [60], shows that contractor's improper planning, contractor's poor site management, inadequate contractor experience, inadequate client's finance and payments for completed work, and problems with subcontractors were found to be the most important factors causing a delay in Australia, Malaysia, and Ghana construction projects.

Based on the report from a questionnaire survey, [51], delay in progress payments (funding problems), different tactics patterns for bribes, shortage of equipment, ineffective project planning, and scheduling, and poor site management and supervision were explored as the major five factors for delays of road construction projects in Egypt. Wa'el, et al., [45], ranked the significant factors causing a delay in building construction projects in Malaysia. Financial difficulties and economic problems, financial problems, supervision too late and slowness in making decisions, slow to give instructions and lack of materials on the market, and poor site management and materials shortages on site were the top-ranked causes of delay. Aliyeh, et al., [5], identified and prioritized delay factors in Iran's oil construction projects. Personal differences between employees, frequent change of managers, and misunderstanding of owner requirements by the design engineer were the most crucial factors. 


\section{Conclusion}

Delay in delivery time is becoming a problem in the construction industry due to its effect on project success. Researchers across the world focused to identify its source, effect, and to provide practice, and suggest various measures for improvement. To gain an in-depth understanding of the research trend in this discipline, this study conducts a review of the critical factors causing delays in construction projects that were published from 2002 to 2020 .

Randomly selected research publications containing relevant information for this study was used for analysis purpose. In the reviewed papers; literature, questionnaire, interview, case study, and document review were the major source and tools of data collection. The analysis techniques of the reviewed papers were relative importance index, average score, simple percentage, mean score, principal component analysis, and other statistical methods. The focus of the published papers is construction, building, and housing, road projects, gas pipeline projects, water and sewer projects.

There is a lack of work that approaches the research problem from a wider industrial context. So the study should be extended to other construction sectors like the dam, bridge, and industrial projects. By geographical coverage, the review papers for this study are from nineteen (19) countries. As the major factor causes of delay vary from one country to the other additional study could be conducted to the rest of the countries. Also, all of the reviewed papers have focused on all categories of delay causes in general and there should be a study for each category of delay specifically to explore detailed causative factors and prepare adequate strategies. Most of the existing studies have used descriptive statistics and statistical analysis methods for data processing. There should be a study that implements simulation and or modeling and other methods of delay estimation.

\section{References}

[1] S. F. Arshi and M. E. Sameh, "Significant factors causing delay in the UAE construction industry," Construction Management and Economics, vol. 24(11), pp. 11671176, 2006. http://dx.doi.org/10.1080/01446190600 827033.

[2] M. Khoshgoftar, A. H. Abu-Bakar and O. Osman, "Causes of Delays in Iranian Construction Projects,"
International Journal of Construction Management, vol 10(2), pp. 53-69., 2010.

[3] C. O. Aigbavboa, W. D. Thwala and M. J. Mukuka, "Construction Project delays in Lusaka, Zambia: Causes and Effects," Journal of Economics and Behavioral Studies, vol. 6(11), pp. 848-857, 2014.

[4] R. Vahid and S. A. Abbas, "Designing Pattern for Project Delay Analysis with Several Periods Extension of Time; Continuous and Discrete (Pr-to-Pr)," Computers \& Industrial Engineering, 2020. https://doi.org/10.1016/j.cie.2020.106576.

[5] K. Aliyeh , K. Eun-Seok and K. Mohammad-Hossein , "Identifying and prioritizing delay factors in Iran's oil construction projects," International Journal of Energy Sector Management, Emerald Publishing Limited, 2020. DOI 10.1108/IJESM-04-2020-0006.

[6] A. A. Khaled , H. H. Ayman and E. N. Gamal , "Guideline for preparing comprehensive extension of time (EoT) claim," HBRC Journal, 2014. http://dx.doi.org/10.1016/j.hbrcj.2014.01.005.

[7] M. Jamil, N. A. Mufti and S. Dar Waseem, "Analysis of Time Slippage for Construction Projects in Public Sector: Owner's Perspective," Mehran University Research Journal of Engineering \& Technology, vol. 31(4), pp. 1216, 2012.

[8] E. Adnan, A. Jomah and K. Mohan, "Delays and cost overruns in the construction projects in the Gaza Strip," Journal of Financial Management of Property and Construction, vol. 14(2), pp. 126-151, https://doi.org/10.1108/13664380910977592, 2009.

[9] M. Y. Norazian and A. Hamimah , "Issues Associated with Extension of Time (EoT) Claim in Malaysian Construction Industry," Procedia Technology, 2013. doi: 10.1016/j.protcy.2013.12.082.

[10] S. A. Assaf and S. Al-Hejji, "Causes of delay in large construction projects," International Journal of Project Management, vol. 24(4) p. 349-357, 2006.

[11] T. Maritz and H. Prinsloo, "A decision support framework for extension of time claims for the JBCC Principal Building Agreement," Acta Structilia, vol. 23(2), pp. 109-146, 2016. 
[12] A. A. Aibinu and G. O. Jagboro, "The Effects of Construction Delays on Project Delivery in Nigerian Construction Industry," International Journal of Project Management, vol. 20, no. 8, pp. 593-599, 2002.

[13] G. J. Kikwasi, "Causes and Effects of Delays and Disruptions in Construction Projects in Tanzania," Australasian Journal of Construction Economics and Building, vol. 1(2), pp. 52-59, 2012.

[14] A.-M. George and D. K. Andrew, "The professionals perspective on the causes of project delay in the construction industry," Engineering, Construction and Architectural Management, 2017.h ttps://doi.org/10.1108/ECAM-03-2016-0085.

[15] M. Amir , T. Mehdi and K. Yahya , "Factors influencing safety performance on construction projects: A review," Safety Science, vol. 109, pp. 382-397, 2018. https://doi.org/10.1016/j.ssci.2018.06.017.

[16] G. Sweis , R. Sweis, A. A. Hammad and A. Shboul, "Delays in construction projects: The case of Jordan," International Journal of Project Management, vol. 26, pp. 665-674, 2008.

[17] S. C. Chang, M. Y. Aminah and H. Hadina, "Delay Mitigation in the Malaysian Housing Industry: A Structural Equation Modelling Approach," Journal of Construction in Developing Countries, vol. 20(1), pp. 6583, 2015.

[18] S. Sohu, A. Chandio and K. Mullh, "Identification of Causes and Minimization of Delays in Highway Projects of Pakistan," Mehran University Research Journal of Engineering \& Technology, vol. 38(1), pp. 103-112, 2019. DOI: $10.22581 /$ muet1982.1901.09

[19] Y. Honrao and D. B. Desai, "Study of Delay in Execution of Infrastructure Projects," International Journal of Scientific and Research Publications, vol. 5(6), pp. 1-8, 2015.

[20] K. Chabota , M. Mundia and M. Kanyuka , "Cost escalation and schedule delays in road construction projects in Zambia," International Journal of Project Management, vol. 27, pp. 522-531, 2009. doi:10.1016/j.ijproman.2008.07.003.
[21] N. Braimah, "An investigation into the use of construction delay and disruption analysis methodologies," PhD dissertation, University of Wolverhampton, 2008.

[22] K. Pickavance, Delay and Disruption in Construction Contracts, 3rd Ed ed., London: LLP Reference Publishing, 2005.

[23] T. J. Trauner, Construction Delay: Understanding Them Clearly, Analysing Them Correctly, 2nd Edition ed., Elsevier, 2009.

[24] J. K. Yates and A. Apstein, "Avoiding and Minimising Construction Delay Claim Disputes in Relational Contracting," Journal of Professional Issues in Engineering Education and Practice, vol. 132(2), pp. 168179, 2006.

[25] F. D. Fugar and A. B. Agyakwah-Baah, "Delays in building construction projects in Ghana," Australasian Journal of Construction Economics and Building, vol. 10(1/2), pp. 103-116, 2010.

[26] I. A. Majid, "Causes and effect of delays in Aceh construction industry," MSc Thesis, 2006.

[27] T. K. Soon, "Dispute resolution in relation to delay of construction projects," MSc Thesis, 2010.

[28] D. K. Frank and B. Adwoa , "Delays in building construction projects in Ghana," Australasian Journal of Construction Economics and Building, vol. 10(1/2), pp. 103-116, 2010.

[29] H. Abdul-Rahman, M. A. Berawi, A. R. Berawi, O. Mohamed, M. Othman and I. A. Yahya, "Delay Mitigation in the Malaysian Construction Industry," Journal of Construction Engineering and Management, vol. 132(2), pp. 125-133, 2006. DOI: 10.1061/ASCE0733-9364.

[30] S. Hamed, M. M. Seyed, T. Pouria , M. H. Ahmad and W. Keith, "Studying the Reasons for Delay and Cost Overrun in Construction Projects: The Case of Iran," Journal of Construction in Developing Countries, vol. 21(1), pp. 51-84, 2016.

[31] A. M. Wa'el, A. Razali and A. S. E. Kadir, "The significant factors causing delay of building construction projects in Malaysia," Engineering, Construction and 
Architectural Management, vol. 14(2), pp. 192206,2007.

http://dx.doi.org/10.1108/09699980710731308.

[32] A. A. Jawad, "Causes of delay in Saudi public construction projects," Alexandria Engineering Journal, vol. 58, p. 801-808, 2019. https://doi.org/10.1016/j.aej. 2019.07.002.

[33] B. H. Y. Jeffrey , . L. G. Pei, B. W. Yoke and S. Martin , "Revisiting critical delay factors for construction: Analysing projects in Malaysia," Alexandria Engineering Journal, https://doi.org/10.1016/j.aej.2020.11.021, 2020.

[34] M. M. Mohamed and I. E.-R. Tarek , "Analyzing delay causes in Egyptian construction projects," Journal of Advanced Research, vol. 5, p. 49-55, 2014.

[35] T. . I. Olajide , O. O. Timo , . A. Onaopepo and V. . E. Idowu , "Analysis of Non-Excusable Delay Factors Influencing Contractors' Performance in Lagos State, Nigeria," Journal of Construction in Developing Countries, vol. 18(1), pp. 53-72, 2013.

[36] D. Y. Kim and S. Chi, "Causes of Schedule Delays in Building Construction Projects in Vanuatu," Journal of Korea Institute of Building Construction, vol. 15(6), 2015. http://dx.doi.org/10.5345/JKIBC.2015.15.6.641

[37] G. Tsegay and L. Hanbin, "Analysis of Delay Impact on Construction Project Based on RII and Correlation Coefficient: Empirical Study," Primosten, Croati, 2017.

[38] T. A. Charles, A. A. Yaa , A. Ebenezer and F. Samuel, "Analysing delay causes and effects in Ghanaian state housing construction projects," International Journal of Managing Projects in Business, vol. 8, no. 1, pp. 198 214 http://dx.doi.org/10.1108/IJMPB-04-2014-0035, 2015 .

[39] D. Hossein , J. O. J, M. Wolfgang and L. Craig , "A cartography of delay risks in the Australian construction industry: impact, correlations and timing," Engineering, Construction and Architectural Management, 2020. DOI 10.1108/ECAM-04-2020-0230.

[40] A. Charles, N. Alfred and A. Okanta, "Exploring critical road project delay factors in Ghan," Journal of Facilities Management, vol. 15(2), 2017. http://dx.doi.org/10.1108 /JFM-09-2016-0036.
[41] E.-R. Tarek and M. Mohamed, "Fuzzy model for assessing delays in Egyptian residential projects," Journal of Financial Management of Property and Construction, vol. 25(2), pp. 225-246, 2020. DOI 10.1108/JFMPC-042019-0031.

[42] M. O. Abdalla and T. B. Hussien, "Causes of construction delay: traditional contracts," International Journal of Project Management, vol. 20, pp. 67-73, 2002.

[43] F. Yaw, . O. Jacob and C. Lynn, "Causes of delay and cost overruns in construction of groundwater projects in a developing countries; Ghana as a case study," International Journal of Project Management, vol. 21, pp. 321-326, 2003. doi:10.1016/S0263-7863(02)00055-8

[44] A. A. Ajibade and A. O. Henry , "Construction Delays and Their Causative Factors in Nigeria," Journal of Construction Engineering and Management, vol. 132, pp. 667-677, 2006.

[45] A. M. Wa'el, A. Razali and A. S. Kadir , "The significant factors causing delay of building construction projects in Malaysia," Engineering, Construction and Architectural Management, vol. 14, no. 2, pp. 192-206, 2007.

[46] H. M, L. Xinhai, B. Aneesa, U. D. Maloof and R. Wahab , "Causes and Effects of Delays in Large Construction Projects of Pakistan," Kuwait Chapter of Arabian Journal of Business and Management Review, vol. 1(4), pp. 1842, 2011

[47] D. Hemanta, S. Anil , . I. K.C and R. Sameer, "Analysing factors affecting delays in Indian construction projects," International Journal of Project Management, vol. 30, pp. 479-489, 2012. doi:10.1016/j.ijproman.2011.10.004.

[48] H. F. Mohammad, "Delay causes in Iran gas pipeline projects," International Journal of Project Management, vol. 31, pp. 136-146, 2013. doi:10.1016/j.ijproman.2012. 06.003.

[49] G. Murat, N. Yasemin and Ö. Mustafa, "Quantification of Delay Factors Using the Relative Importance Index Method for Construction Projects in Turkey," Journal of Management in Engineering, vol. 29(2), pp. 133-139, 2013. DOI: 10.1061/(ASCE)ME.1943-5479.0000129

[50] F. A. Remon, "Ranking of delay factors in construction projects after Egyptian revolution," Alexandria 
Engineering Journal, vol. 52, pp. 387-406, 2013. http://dx.doi.org/10.1016/j.aej.2013.03.002.

[51] F. A. Remon and A. A.-H. Asmaa , "Exploring delay causes of road construction projects in Egypt," Alexandria Engineering Journal, vol. 55, pp. 1515-1539, 2016. http://dx.doi.org/10.1016/j.aej.2016.03.006.

[52] M. K. Abdurezak and . S. Neway, "Causes of Delay in Public Building Construction Projects: A Case of Addis Abeba Administration, Ethiopia," Asian Journal of Managerial Science, vol. 8(2), pp. 4-9, 2019.

[53] S. Samiullah, C. Abdul Fattah and Kaleemullah, "Identification of Causes and Minimization of Delays in Highway Projects of Pakistan," Mehran University Research Journal of Engineering \& Technology, vol. $38(1), \quad$ pp. $103-112, \quad 2019 . \quad$ DOI: 10.22581/muet1982.1901.09.

[54] A. Abderisak, B. J. Per-Erik and L. Göran, "Aggregation of factors causing cost overruns and time delays in large public construction projects: Trends and implications," Engineering, Construction and Architectural Management, vol. 24(3), pp. 393-406, 2017. https://doi.org/10.1108/ECAM-09-2015-0135.

[55] H. Manoj , J. Suresh and R. Urvashi , "Factors affecting collaboration in supply chain: A literature Review," Procedia - Social and Behavioral Sciences, 2013. doi: 10.1016/j.sbspro.2014.04.184.

[56] L. Zhengdao, Q. S. Geoffrey and X. Xiaolong, "Critical review of the research on the management of prefabricated construction," Habitat International, vol. 43, pp. 240-249, 2014.

[57] Y. Ke, S. Wang, A. P. Chan and E. Cheung, "Research trend of publiceprivate partnership in construction journals," Journal of Construction Engineering and Management, vol. 135, pp. 1076-1086, 2009.

[58] . O. M. Mydin, M. N. Sani, M. Taib and M. N. Alias, "Imperative Causes of Delays in Construction Projects from Developers' Outlook," MATEC Web of Conferences, 2014. DOI: 10.1051/ matecconf/ 2014100 005.

[59] S. Murali and W. S. Yau, "Causes and effects of delays in Malaysian construction industry," International
Journal of Project Management, vol. 25, p. 517-526, 2007. doi:10.1016/j.ijproman.2006.11.007.

[60] K. S. Raj, "An Exploration of Causes for Delay and Cost Overruns in Construction Projects: Case Study of Australia, Malaysia \& Ghana," Journal of Advanced College of Engineering and Management, vol. 2, 2016. 